\title{
Optimal Operation Conditions for a Methane Fuelled SOFC and Microturbine Hybrid System
}

\author{
Vincenzo De Marco, Gaetano Florio, and Petronilla Fragiacomo \\ Department of Mechanical, Energy and Management Engineering, University of Calabria, Arcavacata, Rende, 87036 Cosenza, Italy \\ Correspondence should be addressed to Petronilla Fragiacomo; petronilla.fragiacomo@unical.it
}

Received 30 June 2015; Revised 15 October 2015; Accepted 18 October 2015

Academic Editor: Wei-Hsin Chen

Copyright ( 2015 Vincenzo De Marco et al. This is an open access article distributed under the Creative Commons Attribution License, which permits unrestricted use, distribution, and reproduction in any medium, provided the original work is properly cited.

\begin{abstract}
The study of a hybrid system obtained coupling a methane fuelled gas microturbine (MTG) and a solid oxide fuel cell (SOFC) was performed. The objective of this study is to evaluate the operation conditions as a function of the independent variables of the system, which are the current density and fuel utilization factor. Numerical simulations were carried out in developing a C++ computer code, in order to identify the preferable plant configuration and both the optimal methane flow and the current density. Operation conditions are able to ensure elasticity and the most suitable fuel utilization factor. To confirm the reliability of the models, results of the simulations were compared with reference results found in literature.
\end{abstract}

\section{Introduction}

The question of energy savings and optimization of resources is, nowadays, of primary importance, in both economic and environmental fields. In order to respect the Kyoto protocol it is important to invest in new forms of livelihood energy $[1,2]$. The present work lies as part of these problems. An assigned hybrid system resulting from the coupling of a solid oxide fuel cell (SOFC) with a gas microturbine (MTG) was analyzed. For this purpose a $\mathrm{C}++$ code was developed, so that it was possible to define the optimal conditions of operation of the system as a function of the current density dfc of the fuel cell and the fuel utilization $\left(U_{f}\right)$. It has to be pointed out that only by developing such $\mathrm{C}++$ code taking into account both chemical and physical phenomena (i.e., balance of power, chemical reactions, and change in the composition) was it possible to appreciate the difference in performance by comparing different plant schemes. Such calculations match with the current direction taken by the state of the art (i.e., the presence of an afterburner in place of a direct stream from the SOFC stack to the turbine). Although it is still difficult to find experimental data to validate the model completely, this was subjected to comparison with another model present in the literature. It is important to highlight that this kind of approach can be easily adapted to other kinds of plants, only by changing the parameters utilized and by correctly defining the events considered. In this specific case, for the analysis of the gas turbine the data plate of the MTG Ansaldo $100 \mathrm{~kW}$ was taken as a reference, as well as in [3-7]. This type of system can reach values comparable to those of large size, from an efficiency point of view. This is why many researchers have been working for years in order to assess the most appropriate type of application [8-11]. Other types of similar systems, studied with the same approach, are those that focus more on evaluating the potential for residential cogeneration systems (SOFC-CHP) [12], those that evaluate coupling between SOFC and gas turbine of greater power (SOFC-GT) [13-15], or those that take into account molten carbonates fuel cell (MCFC) instead of SOFC [16-22]. In the same field specific SOFC-MTG can vary the nature of the fuel (which in this case is pure methane but which may be, e.g., synthesis gas or biomass) [14, 21-27] and there are also those that try, despite the fact that the state-of-the-art technology in question is not consolidated, a first economic evaluation $[27,28]$. Even the same mathematical model can see different approaches. In this work, for example, a linear law is assumed as a function of temperature for the calculation of the current density of anodic and cathodic exchange, necessary for the 
calculation of activation losses, while in other works this is considered constant [23]. With regard to the current density limit, valid for the calculation of losses due to concentration, in this paper we consider the same for cathode and anode, while elsewhere, in spite of slight differences of the results, a diversification is operated [14]. Another approach, for the calculation of the cell voltage, is the use of a polynomial function of the current by which it calculates a reference voltage and the next calculation of the deviation from this voltage due to the temperature, the operating pressure, and the molars fractions of the different components [29]. In this case, from the definition of the limits of physical, chemical, and technological achievements of different components, the parameters "free" of the system and the range within which the values should vary were identified.

\section{System Configurations}

The system used as reference in this work is a hybrid system (MTG + SOFC) described in [3]. Here, in addition to the SOFC and MTG, there are a prereformer, an afterburner, and an ejector, in which methane is mixed with the gas recirculation. This type of system is capable of providing, at the design point, an electric power to the axis equal to $428 \mathrm{~kW}$, divided into $319 \mathrm{~kW}$ produced by the fuel cell and $109 \mathrm{~kW}$ by gas turbine. The power spent by the two compressors (air and fuel) is, respectively, of $148 \mathrm{~kW}$ and $13 \mathrm{~kW}$, for an efficiency of 0.61 and a TIT of $1240 \mathrm{~K}$. Table 1 shows the main technical and thermodynamic data of the gas turbine and the cell and the meaning of both streams and blocks present in the following plant schemes. In this work, three different system configurations were analyzed, namely, the "base system," the "system with prereformer," and the "complete system." In both the second and the third configuration a component is added, with respect to the previous scheme. Compared to the system studied in [3], there is no ejector. The working pressure of the methane is assumed to be the same as that of the SOFC.

2.1. Base System. Figure 1 shows the diagram of the base system. The anode exhaust (in red) is divided into two parts: the left side exhaust is sent to the recirculation, while the right side flow enters the gas turbine. This stream finally unifies the cathode exhaust to make its entry in the expander. The exit gas from the turbine reaches the heat exchanger, where it provides thermal energy to preheat the air drawn from the MTG compressor. The "regenerated" air (in black) then enters the fuel cell from the cathode side. The recirculation is mixed with the pressurized methane (yellow) to enter then together the anode of the fuel cell (green).

2.2. System with Prereformer. The operation of the system with prereformer (Figure 2) differs, with respect to the hybrid system shown in Figure 1, only because of the presence of the prereformer. In the latter component, the mixture of methane and gas recirculation enters, so that a part of the methane is converted into hydrogen externally to the cell.
TABLE 1: Basic parameters of the components of the hybrid system and streams and blocks meaning in plant schemes.

\begin{tabular}{|c|c|}
\hline $\begin{array}{l}\text { Turbomachinery } \\
\text { configuration }\end{array}$ & Radial \\
\hline Compression ratio & 3.9 \\
\hline $\begin{array}{l}\text { Compressor isentropic } \\
\text { efficiency }\end{array}$ & 0.75 \\
\hline $\begin{array}{l}\text { Expander isentropic } \\
\text { efficiency }\end{array}$ & 0.85 \\
\hline Air flow $[\mathrm{kg} / \mathrm{s}]$ & 0.808 \\
\hline $\begin{array}{l}\text { MTG mechanical power } \\
{[\mathrm{kW}]}\end{array}$ & 110 \\
\hline Rotation speed [rpm] & 64000 \\
\hline $\begin{array}{l}\text { Maximum turbine inlet } \\
\text { temperature }[\mathrm{K}]\end{array}$ & 1250 \\
\hline Burner power $[\mathrm{kW}]$ & 300 \\
\hline SOFC configuration & Tubular \\
\hline Anode thickness [mm] & 0.1 \\
\hline Cathode thickness [mm] & 2.2 \\
\hline $\begin{array}{l}\text { Interconnection thickness } \\
{[\mathrm{mm}]}\end{array}$ & 0.085 \\
\hline Electrolyte thickness [mm] & 0.04 \\
\hline Combustion efficiency & 0.98 \\
\hline Heat exchanger efficiency & 0.87 \\
\hline $\begin{array}{l}\text { Current density }(\mathrm{dfc}) \\
{\left[\mathrm{A} / \mathrm{m}^{2}\right]}\end{array}$ & $2000-3600$ \\
\hline Fuel utilization $\left(U_{f}\right)$ & $0.7-0.9$ \\
\hline Stream 1 & $\begin{array}{c}\text { Cold compressed air entering the } \\
\text { heat exchanger }\end{array}$ \\
\hline Stream 2 & $\begin{array}{l}\text { Hot compressed air entering the } \\
\text { cathode }\end{array}$ \\
\hline Stream 3 & Uncompressed $\mathrm{CH} 4$ \\
\hline Stream 4 & Compressed $\mathrm{CH} 4$ \\
\hline Stream 5 & $\begin{array}{l}\text { CH4 and anode outlet mixture } \\
\text { entering the anode }\end{array}$ \\
\hline Stream 6 & Anode outlet \\
\hline Stream 7 & Anode outlet mixing with $\mathrm{CH} 4$ \\
\hline Stream 8 & $\begin{array}{c}\text { Anode outlet mixing with cathode } \\
\text { outlet }\end{array}$ \\
\hline Stream 9 & Cathode outlet \\
\hline Stream 10 & Mixture entering the turbine \\
\hline Stream 11 & $\begin{array}{c}\text { Turbine outlet entering the heat } \\
\text { exchanger }\end{array}$ \\
\hline Stream 12 & Heat exchanger outlet \\
\hline Stream 13 & $\begin{array}{l}\mathrm{CH} 4 \text { and anode outlet mixture } \\
\text { entering the prereformer }\end{array}$ \\
\hline Stream 14 & $\begin{array}{l}\text { Prereformer outlet entering the } \\
\text { anode }\end{array}$ \\
\hline Stream 15 & $\begin{array}{c}\text { Afterburner outlet entering the } \\
\text { turbine }\end{array}$ \\
\hline Stream 16 & Mixer outlet \\
\hline Block A & Air compressor \\
\hline Block B & Turbine \\
\hline Block C & Alternator \\
\hline Block D & $\mathrm{CH} 4$ compressor \\
\hline Block E & Heat exchanger \\
\hline Block F & Inverter \\
\hline Block G & Solid oxide fuel cell \\
\hline Block H & Prereformer \\
\hline Block I & Afterburner \\
\hline Block J & Mixer \\
\hline
\end{tabular}




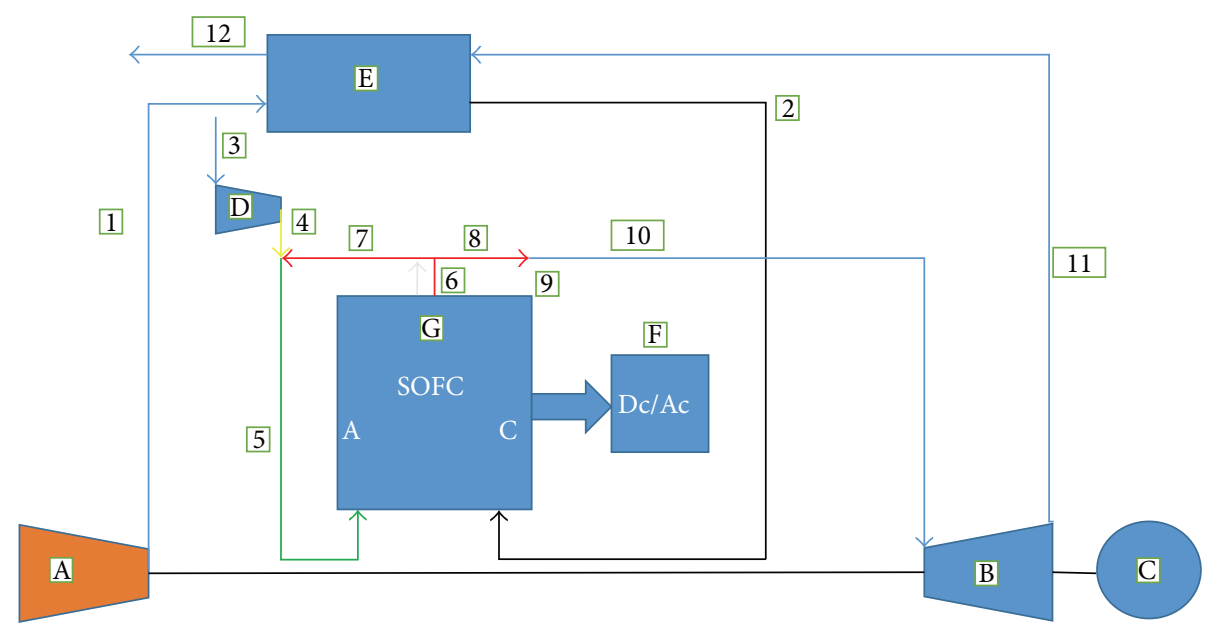

FIgURE 1: Technical scheme of the base system.

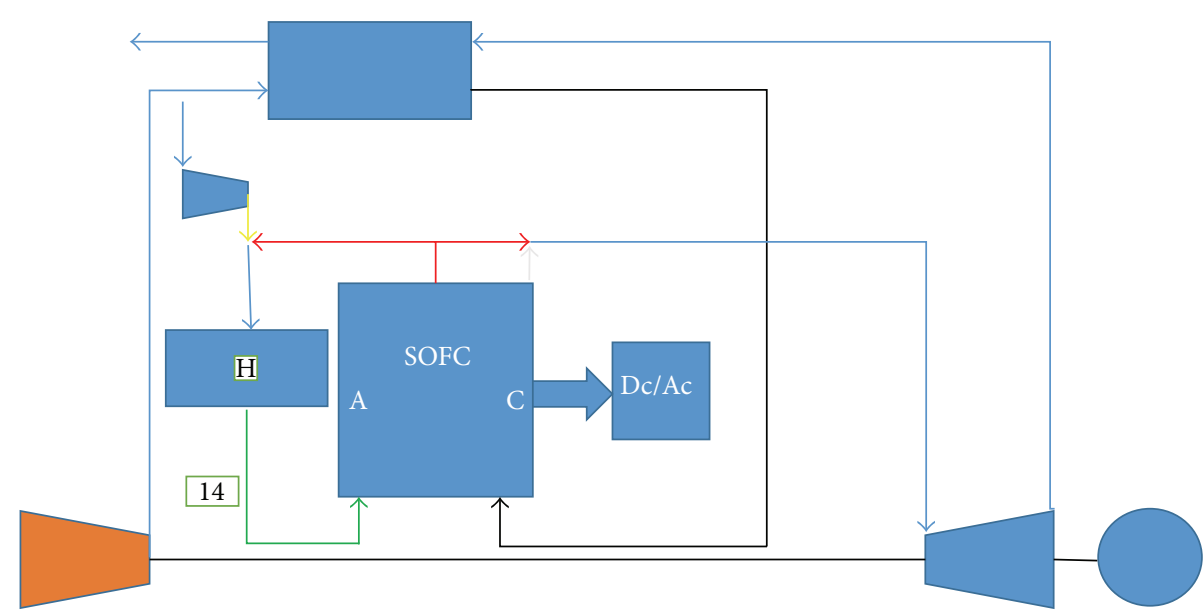

FIgURE 2: Technical scheme of the system with prereformer.

2.3. Complete System. In the case of complete system (Figure 3), the difference from the previous configuration is that the anode exhaust not sent to recirculation is sent downstream of SOFC, where an afterburner (or postcombustor) provides for oxidization of the hydrogen and carbon monoxide residues. The cathode exhaust provides the oxygen to the afterburner, while the products of the postcombustor constitute the working fluid of the expander of MTG. The rest of the system is entirely analogous to the previous configurations.

\section{Mathematical Model}

Here, the procedures used for the calculation of the main variables of the hybrid system as a function of $U_{f}$ and dfc are described: recirculation flow, temperatures of mixing between recirculation and methane input anode cell operation, of afterburning, and of inlet air to the cathode, percentage of methane converted from the prereformer, and various performance parameters, that is, power output and efficiency. Calculation of flow recirculation: we calculate the air recirculation rate according to

$$
n_{\text {ric }}=\frac{n_{\mathrm{H}_{2} \text { ric }}}{f_{\mathrm{H}_{2}}}
$$

where the calculation of $n_{\mathrm{H}_{2} \text { ric }}$ is done using

$$
n_{\mathrm{H}_{2} \text { ric }}=\frac{z / U_{f}-3 n_{\mathrm{CH}_{4}}}{\left(1+0.3 f_{\mathrm{CO}} / f_{\mathrm{H}_{2}}\right)},
$$

where $z$ is given by

$$
z=\frac{\mathrm{dfc} \cdot A_{f}}{2 F} .
$$

So, once $U_{f}$ and $\mathrm{dfc}$ are assigned, the recirculation flow is therefore uniquely defined. Calculation of the temperature of mixing between recirculation anodic and pressurized methane ( $T_{\text {mix }}$ block $A$ in Figure 5): a mixture formed by gas recirculation and methane out from the compressor enters the fuel 


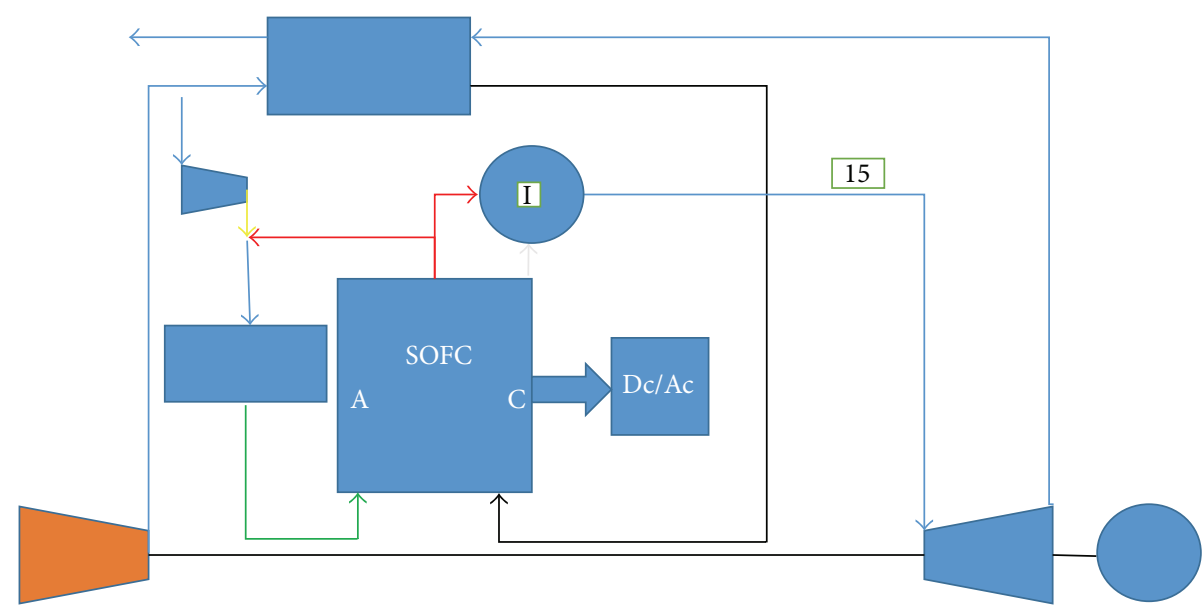

Figure 3: Technical scheme of complete system.

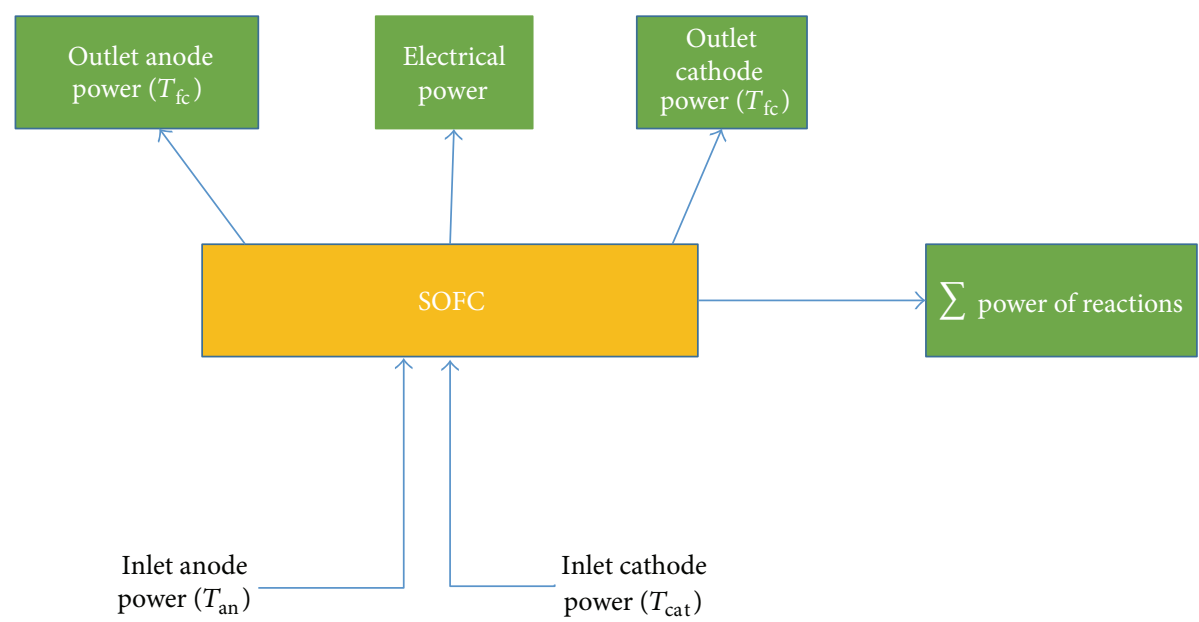

FIgURE 4: Flow input power and output from the fuel cell.

cell. The anode inlet temperature is calculated by attempts by the balance of thermal power expressed by

$$
\begin{aligned}
n_{\mathrm{CH}_{4}} & \cdot h_{\mathrm{CH}_{4}}(600 K)+n_{\mathrm{H}_{2} \mathrm{O}} \cdot h_{\mathrm{H}_{2} \mathrm{O}}\left(T_{\mathrm{fc}}\right)+n_{\mathrm{H}_{2}} \\
& \cdot h_{\mathrm{H}_{2}}\left(T_{\mathrm{fc}}\right)+n_{\mathrm{CO}} \cdot h_{\mathrm{CO}}\left(T_{\mathrm{fc}}\right)+n_{\mathrm{CO}_{2}} \cdot h_{\mathrm{CO}_{2}}\left(T_{\mathrm{fc}}\right) \\
= & n_{\mathrm{CH}_{4}} \cdot h_{\mathrm{CH}_{4}}\left(T_{\text {mix }}\right)+n_{\mathrm{H}_{2} \mathrm{O}} \cdot h_{\mathrm{H}_{2} \mathrm{O}}\left(T_{\text {mix }}\right)+n_{\mathrm{H}_{2}} \\
& \cdot h_{\mathrm{H}_{2}}\left(T_{\text {mix }}\right)+n_{\mathrm{CO}} \cdot h_{\mathrm{CO}}\left(T_{\text {mix }}\right)+n_{\mathrm{CO}_{2}} \\
& \cdot h_{\mathrm{CO}_{2}}\left(T_{\text {mix }}\right) .
\end{aligned}
$$

When (4) reaches convergence, the same $T_{\text {mix }}$ represents the unknown searched. Calculation of moles of methane converted from the prereformer ( $x$, block $A$ in Figure 5): this parameter is obtained by attempts, starting from $x$ of hypotheses to obtain the one that satisfies the power balance to prereformer. Inside the prereformer coupled reactions of steam reforming reaction and that, coupled to it, of Water Gas Shift Reaction (WGSR) occur, expressed by

$$
\begin{gathered}
\mathrm{CH}_{4}+\mathrm{H}_{2} \mathrm{O} \longleftrightarrow 3 \mathrm{H}_{2}+\mathrm{CO} \\
\mathrm{CO}+\mathrm{H}_{2} \mathrm{O} \longleftrightarrow \mathrm{CO}_{2}+\mathrm{H}_{2}
\end{gathered}
$$

The ratio between (6) and (5) speed of reaction is unknown. We proceeded by calculating the speed of reactions for the operating temperatures of the SOFC and for different percentages of reforming, using as a parameter the convergence of equilibrium constants defined by

$$
\begin{aligned}
K_{\text {ref }} & =\frac{\left[\mathrm{H}_{2}\right]^{3} \cdot[\mathrm{CO}]}{\left[\mathrm{CH}_{4}\right] \cdot\left[\mathrm{H}_{2} \mathrm{O}\right]} P^{2}, \\
K_{\text {shif }} & =\frac{\left[\mathrm{H}_{2}\right] \cdot\left[\mathrm{CO}_{2}\right]}{[\mathrm{CO}] \cdot\left[\mathrm{H}_{2} \mathrm{O}\right]}
\end{aligned}
$$




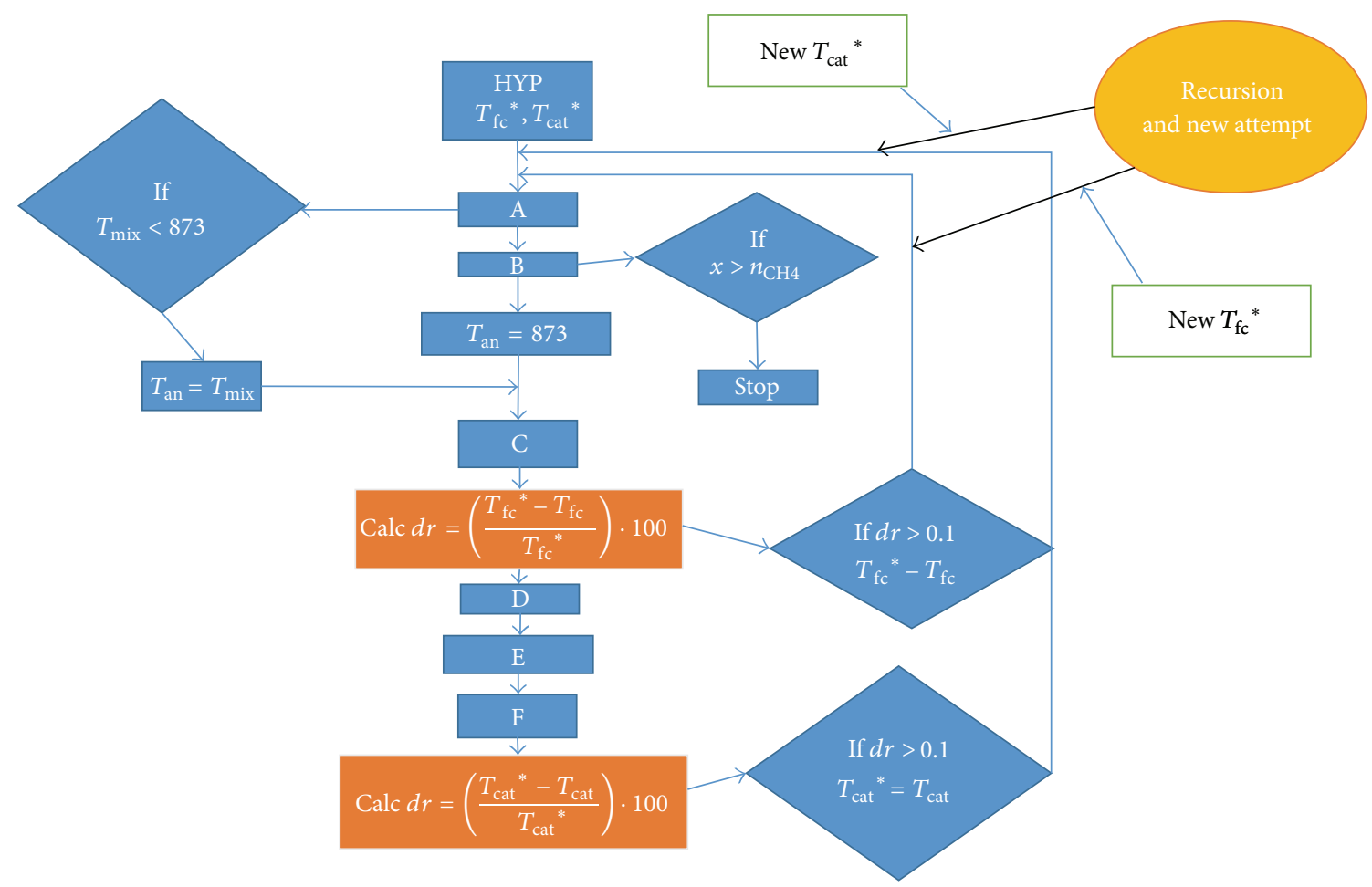

FIgURE 5: Flow diagram for the calculation of the parameters of the complete system.

and comparing (7) and (8) with the values of the equilibrium constants calculated as a function of the temperature according to

$$
\log K=A \cdot T^{4}+B \cdot T^{3}+C \cdot T^{2}+D \cdot T+E .
$$

Table 2 shows the values of the constants relating to (9) for the two reactions. The average ratio between speed of (6) and speed of (5) is equal on average to about 0.3. Equations (7) and (8) are taken from [31], while (9) is taken from [30]. Therefore, in the calculations of the mass balance and thermal power balance, we consider that, for each mole of $\mathrm{CH}_{4}$ converted, 0.3 moles of $\mathrm{H}_{2}$ is also generated from the conversion of $\mathrm{CO}$ produced by (6). In light of this approximation, the power balance to the prereformer appears to be expressed by

$$
\begin{aligned}
n_{\mathrm{CH}_{4}} & \cdot h_{\mathrm{CH}_{4}}\left(T_{\text {mix }}\right)+n_{\mathrm{H}_{2} \mathrm{O}_{\mathrm{ip}}} \cdot h_{\mathrm{H}_{2} \mathrm{O}}\left(T_{\text {mix }}\right)+n_{\mathrm{H}_{2 \mathrm{ip}}} \\
& \cdot\left(T_{\mathrm{mix}}\right)+n_{\mathrm{CO}_{\mathrm{ip}}} \cdot h_{\mathrm{CO}}\left(T_{\mathrm{mix}}\right)+n_{\mathrm{CO}_{2 \mathrm{ip}}} \\
& \cdot h_{\mathrm{CO}_{2}}\left(T_{\mathrm{mix}}\right)-x \cdot \Delta h_{\mathrm{ref}}-0.3 x \cdot \Delta h_{\text {shif }} \\
= & \left(n_{\mathrm{CH}_{4 \mathrm{ip}}}-x\right) \cdot h_{\mathrm{CH}_{4}}(873)+\left(n_{\mathrm{H}_{2} \mathrm{O}_{\mathrm{ip}}}-1.3 x\right) \\
& \cdot h_{\mathrm{H}_{2} \mathrm{O}}(873)+\left(n_{\mathrm{H}_{2 \mathrm{ip}}}+1.3 x\right) \cdot(873) \\
& +\left(n_{\mathrm{CO}_{\mathrm{ip}}}+0.7 x\right) \cdot h_{\mathrm{CO}}(873)+\left(n_{\mathrm{CO}_{2 \mathrm{ip}}}+0.3 x\right) \\
& \cdot h_{\mathrm{CO}_{2}}(873) .
\end{aligned}
$$

TABLE 2: Values for the calculation of the equilibrium constant $K$ [30].

\begin{tabular}{lcc}
\hline & Reforming & Shifting \\
\hline A & $2.6312 \cdot 10^{-11}$ & $5.47 \cdot 10^{-12}$ \\
B & $1.2406 \cdot 10^{-7}$ & $-2.574 \cdot 10^{-8}$ \\
C & $-2.2523 \cdot 10^{-4}$ & $4.6374 \cdot 10^{-5}$ \\
D & $5.12749 \cdot 10^{-1}$ & $-3.915 \cdot 10^{-2}$ \\
E & -66.139488 & 13.209723 \\
\hline
\end{tabular}

Operating Temperature of the Cell $\left(T_{\mathrm{fc}}\right.$, Block $C$ in Figure 5). An iterative method for the calculation of the operating temperature of the cell is used as well. We start from a temperature of attempt until the convergence of power balance is reached. This last is expressed by

$$
\begin{aligned}
n_{\mathrm{CH}_{4}} & \cdot h_{\mathrm{CH}_{4}}\left(T_{\mathrm{an}}\right)+n_{\mathrm{H}_{2} \mathrm{O}_{\mathrm{ifc}}} \cdot h_{\mathrm{H}_{2} \mathrm{O}}\left(T_{\mathrm{an}}\right)+n_{\mathrm{H}_{2 \mathrm{ifc}}} \cdot\left(T_{\mathrm{an}}\right) \\
& +n_{\mathrm{CO}_{\mathrm{ifc}}} \cdot h_{\mathrm{CO}}\left(T_{\mathrm{an}}\right)+n_{\mathrm{CO}_{2 \mathrm{ifc}}} \cdot h_{\mathrm{CO}_{2}}\left(T_{\mathrm{an}}\right)+n_{\mathrm{O}_{2 \mathrm{ifc}}} \\
& \cdot h_{\mathrm{O}_{2}}\left(T_{\mathrm{cat}}\right)+n_{\mathrm{N}_{2}} \cdot h_{\mathrm{N}_{2}}\left(T_{\mathrm{cat}}\right)-n_{\mathrm{CH}_{4}} \cdot \Delta h_{\mathrm{ref}} \\
& -0.3 n_{\mathrm{CH}_{4}} \cdot \Delta h_{\mathrm{shif}}-z \cdot \Delta h_{\mathrm{H}_{2} \mathrm{O}} \\
= & n_{\mathrm{H}_{2} \mathrm{O}_{\mathrm{ofc}}} \cdot h_{\mathrm{H}_{2} \mathrm{O}}\left(T_{\mathrm{fc}}\right)+n_{\mathrm{H}_{2 \text { ofc }}} \cdot\left(T_{\mathrm{fc}}\right)+n_{\mathrm{CO}_{\text {ofc }}} \\
& \cdot h_{\mathrm{CO}}\left(T_{\mathrm{fc}}\right)+n_{\mathrm{CO}_{2 \text { ofc }}} \cdot h_{\mathrm{CO}_{2}}\left(T_{\mathrm{fc}}\right)+n_{\mathrm{O}_{2 \text { ofc }}} \\
& \cdot h_{\mathrm{O}_{2}}\left(T_{\mathrm{fc}}\right)+n_{\mathrm{N}_{2}} \cdot h_{\mathrm{N}_{2}}\left(T_{\mathrm{fc}}\right)+\dot{P} .
\end{aligned}
$$


It is interesting to observe graphically the power flow of Figure 4, in which the contributions present in (11) are visible. It is now possible at this stage to calculate the power generated by the cell, through

$$
\dot{P}_{c}=V \cdot I
$$

To calculate $I$ the following equation is used:

$$
I=\mathrm{dfc} \cdot A_{f}
$$

$V$ is obtained by

$$
V=V_{0}-V_{\text {Nernst }}-V_{\text {att }}-V_{\text {ohm }}-V_{\text {conc }}
$$

while (15) is used to calculate $V_{0}$ :

$$
V_{0}=\frac{-\Delta G^{0}}{2 F} .
$$

$V_{\text {Nernst }}$ is given by

$$
V_{\text {Nernst }}=\frac{R T}{2 F} \ln \left(\frac{f_{\mathrm{H}_{2} \mathrm{O}}}{f_{\mathrm{H}_{2}} \cdot f_{\mathrm{O}_{2}}{ }^{0.5}} \cdot P^{0.5}\right) .
$$

$V_{\text {att }}$ is provided by

$$
V_{\mathrm{act}}=V_{\mathrm{act}_{a}}+V_{\mathrm{act}_{c}} \cdot
$$

To calculate $V_{\text {act }_{a}}$ we resort to

$$
V_{\mathrm{act}_{a}}=\left(\frac{R T}{F}\right) \sinh ^{-1}\left(\frac{\mathrm{dfc}}{2 i 0_{a}}\right) .
$$

Analogous calculation of $V_{\text {act }_{c}}$ results by

$$
V_{\mathrm{act}_{c}}=\left(\frac{R T}{F}\right) \sinh ^{-1}\left(\frac{\mathrm{dfc}}{2 i 0_{c}}\right) .
$$

Once losses for activation have been defined, we calculate those for concentration $V_{\text {conc }}$ by

$$
V_{\text {conc }}=\left(\frac{R T}{F}\right) \ln \left(1-\frac{\mathrm{dfc}}{i l}\right) \text {. }
$$

The voltage loss due to the ohmic resistance is obtained by

$$
V_{\mathrm{ohm}}=\mathrm{dfc} \cdot \sum_{i=1}^{4} \frac{L_{i}}{\sigma_{i}} .
$$

From (12) to (15) are taken from [3], whereas the equations in (16) to (21) are taken from [4]. Calculation of afterburning temperature (block D in Figure 5): once it has left the cell, the gas mixture reaches a postcombustor. Here, since the oxidation of both hydrogen and carbon monoxide still present in the anode exhaust, the temperature of the gas rises further. Then the following occur:

$$
\begin{aligned}
& \mathrm{H}_{2}+\frac{1}{2} \mathrm{O}_{2} \longrightarrow \mathrm{H}_{2} \mathrm{O} \\
& \mathrm{CO}+\frac{1}{2} \mathrm{O}_{2} \longrightarrow \mathrm{CO}_{2}
\end{aligned}
$$

By varying $T_{\mathrm{pc}}$ the balance of thermal power is solved, expressed by

$$
\begin{aligned}
n_{\mathrm{H}_{2 i \mathrm{pc}}} & \cdot h_{\mathrm{H}_{2}}\left(T_{\mathrm{fc}}\right)+n_{\mathrm{H}_{2} \mathrm{O}_{\mathrm{ipc}}} \cdot h_{\mathrm{H}_{2} \mathrm{O}}\left(T_{\mathrm{fc}}\right)+n_{\mathrm{CO}_{\mathrm{ipc}}} \\
\cdot & h_{\mathrm{CO}}\left(T_{\mathrm{fc}}\right)+n_{\mathrm{CO}_{2 \mathrm{ipc}}} \cdot h_{\mathrm{CO}_{2}}\left(T_{\mathrm{fc}}\right)+n_{\mathrm{O}_{2 \mathrm{ipc}}} \\
\cdot & h_{\mathrm{O}_{2}}\left(T_{\mathrm{fc}}\right)+n_{\mathrm{N}_{2 \mathrm{ipc}}} \cdot h_{\mathrm{N}_{2}}\left(T_{\mathrm{fc}}\right) \\
& -\eta_{\mathrm{comb}}\left[\left(n_{\mathrm{H}_{2 \mathrm{ipc}}} \cdot \Delta h_{\mathrm{H}_{2} \mathrm{O}}\right)-\left(n_{\mathrm{CO}_{\mathrm{ipc}}} \cdot \Delta h_{\mathrm{CO}_{2}}\right)\right] \\
= & n_{\mathrm{H}_{2} \mathrm{O}_{\mathrm{opc}}} \cdot h_{\mathrm{H}_{2} \mathrm{O}}\left(T_{\mathrm{pc}}\right)+n_{\mathrm{CO}_{2 \mathrm{opc}}} \cdot h_{\mathrm{CO}_{2}}\left(T_{\mathrm{pc}}\right) \\
& +n_{\mathrm{O}_{2 \mathrm{opc}}} \cdot h_{\mathrm{O}_{2}}\left(T_{\mathrm{pc}}\right)+n_{\mathrm{N}_{2 \mathrm{ipc}}} \cdot h_{\mathrm{N}_{2}}\left(T_{\mathrm{pc}}\right) .
\end{aligned}
$$

Once $T_{\mathrm{pc}}$ is known, which also corresponds to the TIT, since we know the isentropic efficiency of the expander MTG, we can easily calculate the temperature of the turbine outlet $\left(T_{\text {out }}\right.$, block E in Figure 5) by

$$
T_{\text {out }}=\mathrm{TIT}-\eta_{\mathrm{is}}\left(\mathrm{TIT}-T_{\mathrm{is}}\right) .
$$

Calculation of the inlet air temperature at the cathode ( $T_{\text {cat }}$, block $F$ in Figure 5): gas mixture, of known composition and temperature $T_{\text {out }}$, once expanded is sent to a countercurrent heat exchanger (or regenerator). Here, as the hot fluid and as the cold, respectively, the mixture under examination and the outlet air from the compressor (at a flow rate equal to $0.808 \mathrm{Kg} / \mathrm{s}$ and at a temperature of $404 \mathrm{~K}$ ) enter. The balance equation of thermal power into the regenerator is expressed by

$$
\begin{aligned}
n_{\text {air }} \cdot & h_{\text {air }}(404 \mathrm{~K})+n_{\mathrm{H}_{2} \mathrm{O}} \cdot h_{\mathrm{H}_{2} \mathrm{O}}\left(T_{\text {out }}\right)+n_{\mathrm{H}_{2}} \\
& \cdot h_{\mathrm{H}_{2}}\left(T_{\text {out }}\right)+n_{\mathrm{CO}} \cdot h_{\mathrm{CO}}\left(T_{\text {out }}\right)+n_{\mathrm{CO}_{2}} \\
& \cdot h_{\mathrm{CO}_{2}}\left(T_{\text {out }}\right)+n_{\mathrm{O}_{2}} \cdot h_{\mathrm{O}_{2}}\left(T_{\text {out }}\right)+n_{\mathrm{N}_{2}} \cdot h_{\mathrm{N}_{2}}\left(T_{\text {out }}\right) \\
= & n_{\text {air }} \cdot h_{\text {air }}\left(T_{e 1}\right)+n_{\mathrm{H}_{2} \mathrm{O}} \cdot h_{\mathrm{H}_{2} \mathrm{O}}\left(T_{e 1}\right)+n_{\mathrm{H}_{2}} \\
& \cdot h_{\mathrm{H}_{2}}\left(T_{e 1}\right)+n_{\mathrm{CO}} \cdot h_{\mathrm{CO}}\left(T_{e 1}\right)+n_{\mathrm{CO}_{2}} \\
& \cdot h_{\mathrm{CO}_{2}}\left(T_{e 1}\right)+n_{\mathrm{O}_{2}} \cdot h_{\mathrm{O}_{2}}\left(T_{e 1}\right)+n_{\mathrm{N}_{2}} \cdot h_{\mathrm{N}_{2}}\left(T_{e 1}\right) .
\end{aligned}
$$

It starts from $T_{e 1}$ attempted and the calculation is iterated until (26) is satisfied. $T_{e 1}$ represents the temperature at which the hot gases exiting the regenerator give part of their thermal power to cogeneration purposes. Once this first phase is completed, the calculation of $T_{\text {cat }}$ through (27) is effected:

$$
n_{\text {air }} \cdot h_{\text {air }}\left(T_{\text {cat }}\right)=n_{\text {air }} \cdot h_{\text {air }}(404 \mathrm{~K})+\dot{P}_{\text {term }} \text {, }
$$

where

$$
\dot{P}_{\text {term }}=0.87 \cdot \dot{P}_{e 1}
$$

Thus, after calculating $T_{\text {cat }}$, the circuit is completely defined. At the following iteration, this temperature $T_{\text {cat }}$ is the input for the calculation of $T_{\mathrm{fc}}$. The cycle continues until all the 
parameters arrive at convergence. Then, the evaluation of performance parameters is made, as follows.

Useful Power of the Cell Calculation $\left(\dot{P}_{\mathrm{uc}}\right)$. Consider

$$
\dot{P}_{\mathrm{uc}}=\eta_{\mathrm{inv}} \cdot \dot{P}_{c} .
$$

Cell Efficiency Calculation $\left(\eta_{c}\right)$. Consider

$$
\eta_{c}=\frac{\dot{P}_{\mathrm{uc}}}{\dot{m}_{\mathrm{CH}_{4}} \cdot \mathrm{LHV}_{\mathrm{CH}_{4}}} .
$$

Gas Turbine Useful Power Calculation $\left(\dot{P}_{\mathrm{tg}}\right)$. Consider

$$
\dot{P}_{\mathrm{tg}}=\dot{P}_{\mathrm{ut}}-\dot{P}_{\mathrm{ac}}
$$

where

$$
\dot{P}_{\mathrm{ut}}=\dot{m}_{t} \cdot \Delta h
$$

Gas Turbine Efficiency Calculation $\left(\eta_{\mathrm{tg}}\right)$. Consider

$$
\eta_{\mathrm{tg}}=\frac{\dot{P}_{\mathrm{tg}}}{\dot{m}_{\mathrm{CH}_{4}} \cdot \mathrm{LHV}_{\mathrm{CH}_{4}}} .
$$

The efficiency and useful power of the entire system are then calculated as the sum of efficiency and useful power of SOFC and MTG. We then calculate the cogeneration indices, that is, IRE,

$$
\mathrm{IRE}=1-\frac{\dot{P}_{\mathrm{tot}}}{\dot{P}_{\mathrm{SI}} / \eta_{\mathrm{SI}}+\dot{P}_{\mathrm{cog}}},
$$

and the thermal limit LT,

$$
\mathrm{LT}=\frac{\dot{P}_{\mathrm{cog}} \cdot \eta_{\mathrm{term}}}{\dot{P}_{\mathrm{tot}}} .
$$

It was assumed that the heat available downstream of the regenerator was transferable with an efficiency of $40 \%$ to a thermodynamic cycle downstream, to calculate the cogenerative values. The procedure described already is summarized in Figure 5.

\section{Constraints Definition}

"Setting" defines a given combination of parameters $\mathrm{dfc}$ and $U_{f}$ with which it is possible to operate the hybrid system. Therefore, the set of all the possible settings by the range within which the parameters themselves can vary is defined (Table 1). By defining the constraints we proceed to identify the settings that are eligible for a given value of the flow of methane, so as to adequately assess the elasticity design connected to the same flow. Steam to Carbon Ratio (STCR): the lower limit of Steam to Carbon Ratio is the first restriction to be taken into account, defined as

$$
\text { STCR }=\frac{n_{\mathrm{H}_{2} \mathrm{O}}}{n_{\mathrm{CO}}+n_{\mathrm{CH}_{4}}} .
$$

The said parameter must remain above 2 . In the event that this limit is not respected the humidification of the anode may not be satisfactory and it may cause cracking of both methane and carbon dioxide molecules, according to the reactions

$$
\begin{aligned}
& \mathrm{CH}_{4} \longrightarrow \mathrm{C}+2 \mathrm{H}_{2} \\
& \mathrm{CO}_{2} \longrightarrow \mathrm{C}+\mathrm{O}_{2}
\end{aligned}
$$

Consequently, we face the catalyst deactivation caused by the presence of carbonaceous deposits.

Constraint on Maximum Current Density. The methane is converted to hydrogen by (5) and (6). Given the assumptions previously made on the kinetics of these reactions, we have that the total conversion of one mole of methane per second gives rise to 3.3 moles of hydrogen per second. Simultaneously, according to (3), $z$ moles of hydrogen per second is instead consumed. Thus, the consumption of hydrogen is directly proportional to the current density. Therefore, the settings that provide a value of $z$ higher with respect to hydrogen product are considered ineligible.

Constraints on the Operating Temperature of the Fuel Cell $\left(T_{\mathrm{fc}}\right)$ and the Turbine Inlet Temperature (TIT). Constraints relating to temperature are the last to be taken into account. We excluded the settings that generate temperatures of the stack higher than typical operating temperatures of SOFCs and have turbine inlet temperatures above $1250 \mathrm{~K}$ (current technological limit of MTG). Thus, we summarize the conditions as follows:
(a) $873 \mathrm{~K}<T_{\text {fc }}<1200 \mathrm{~K}$;
(b) $\mathrm{TIT}<1250 \mathrm{~K}$.

\section{Results}

In this section, we proceed to the choice of the optimal configuration with which the hybrid system works and then to define the methane flow and the operative current density. The next step is sensitivity analysis of the main parameters at varying $U_{f}$, whereas at the end a first validation of the calculation model is operated. Selection of the optimal configuration: the optimum configuration is that of complete system. This choice stems from the following reasoning. According to (2), recirculation flow decreases at increasing $U_{f}$, and, the recirculation being at a temperature higher than compressed methane, this implies a lowering of $T_{\text {mix }}$ which then propagates on all operating parameters of the plant, using as a parameter to control the fall percentage $T_{\mathrm{fc}}$ at varying $U_{f}$, defined by

$$
\begin{aligned}
& \text { fall of temperature [\%] } \\
& \qquad=\frac{T_{\mathrm{fc}}\left(U_{f}=i\right)-T_{\mathrm{fc}}\left(U_{f}=i+0,01\right)}{T_{\mathrm{fc}}\left(U_{f}=i\right)} .
\end{aligned}
$$

See Tables 3 and 4 .

In the case of the base system, the fall of temperature is higher than 5\%. This is considered excessive. By comparing 
TABLE 3: Fall of temperature for increasing $U_{f}$ for base system.

\begin{tabular}{lccc}
\hline $\mathrm{dfc}\left[\mathrm{A} / \mathrm{m}^{2}\right]$ & $U_{f}$ & $T_{\mathrm{fc}}[\mathrm{K}]$ & Fall of temperature [\%] \\
\hline 2500 & 0.81 & 963.9 & \\
2500 & 0.82 & 913.7 & 5.21 \\
\hline
\end{tabular}

TABLE 4: Fall of temperature for increasing $U_{f}$ for system with prereformer.

\begin{tabular}{lccc}
\hline $\mathrm{dfc}\left[\mathrm{A} / \mathrm{m}^{2}\right]$ & $U_{f}$ & $T_{\mathrm{fc}}[\mathrm{K}]$ & Fall of temperature [\%] \\
\hline 2500 & 0.81 & 945.5 & \\
2500 & 0.82 & 911.3 & 3.66 \\
\hline
\end{tabular}

TABLE 5: Comparison between the gas turbine power plant with prereformer and complete system for $\mathrm{dfc}=2500 \mathrm{~A} / \mathrm{m}^{2}$.

\begin{tabular}{lcc}
\hline$U_{f}$ & System with prereformer & Complete system \\
\hline 0.81 & 101.1 & 166.74 \\
0.82 & 92.38 & 154.87 \\
0.83 & 83.02 & 144.83 \\
\hline
\end{tabular}

Tables 3 and 4 it is evident how, for homologous settings, in the case of system with prereformer the condition has improved. Having higher temperatures with lower values $U_{f}$ implies that a significant part of the fuel is not properly used, a phenomenon that has an impact on the values of gas turbine power. Therefore, to remedy this gap is necessary to insert an afterburner downstream of the fuel cell, so that the configuration of the complete system becomes necessary. Table 5 shows how, for homologous conditions, the complete system ensures a significant increase of the gas turbine power.

Definition of Optimum Operating Conditions. The optimum operating conditions, that is, flow of methane and the current density to operate with, are chosen using design flexibility as the criterion. The model developed has been applied to the calculation of the conditions resulting from three different values of flow rate of methane, low $\left(\dot{m}_{b}=0.012 \mathrm{~kg} / \mathrm{s}\right)$, medium $\left(\dot{m}_{m}=0.015 \mathrm{~kg} / \mathrm{s}\right)$, and high $\left(\dot{m}_{a}=0.018 \mathrm{~kg} / \mathrm{s}\right)$. In the case of high flow rate of methane there is no setting compatible with all the constraints. In contrast, from a comparison between Tables 6(a) and 6(b), it is shown that the medium flow rate ensures greater design flexibility, thus resulting in a specific value (asterisks are the settings eligible). Table 6(b) shows how, for $\mathrm{dfc}=2900 \mathrm{~A} / \mathrm{m}^{2}$, there is a greater choice of the possible settings that satisfy all the constraints outlined above, so that this value is identified as the operating current density and is used in the following sensitivity analysis.

Sensitivity of Operating Parameters and Performance at Varying $U_{f}$. A sensitivity analysis is performed to determine the effect of varying $U_{f}$ on the operating parameters and performance. According to (2), the recirculation flow decreases at increasing $U_{f}$ (first effect). Consequently, all operating temperatures of the plant should decrease. However, the decrease of recirculation flow implies a greater flow to the afterburner
TABLE 6: Plan of the possible settings for low and medium flow rate of methane.

(a)

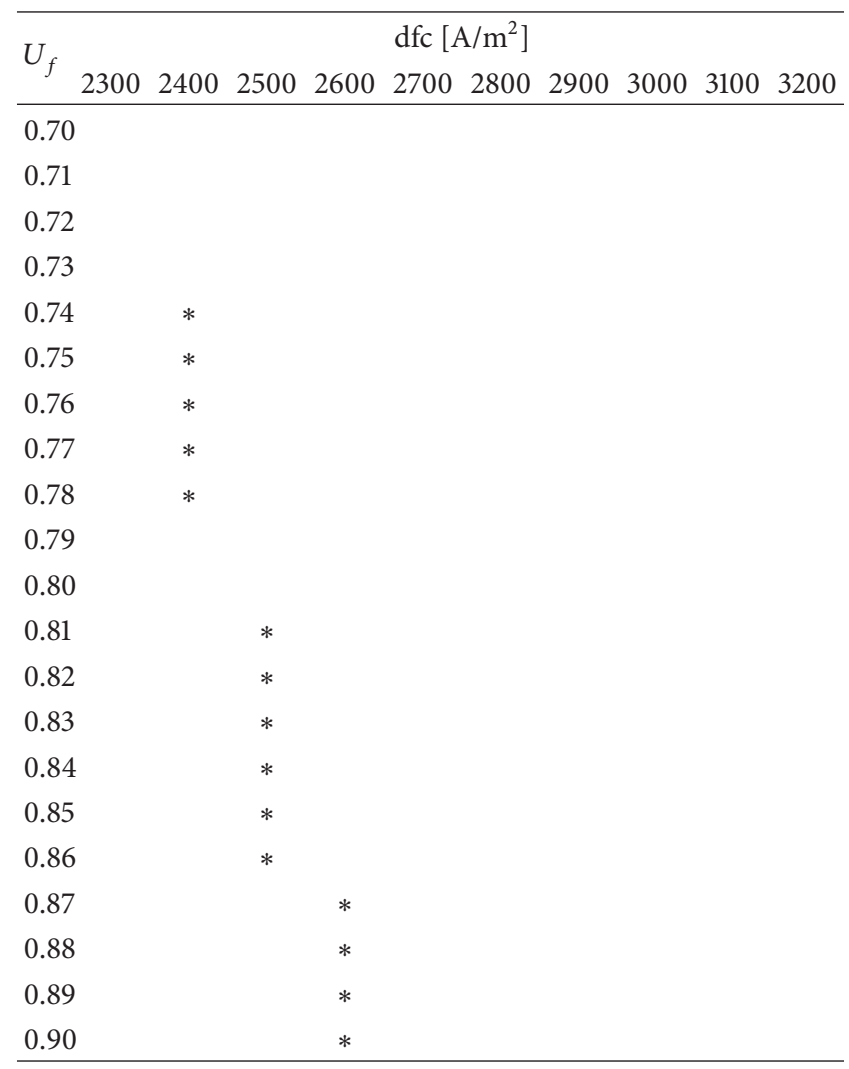

(b)

\begin{tabular}{|c|c|c|c|c|c|c|c|c|c|c|}
\hline \multirow{2}{*}{$U_{f}$} & \multicolumn{10}{|c|}{$\mathrm{dfc}\left[\mathrm{A} / \mathrm{m}^{2}\right]$} \\
\hline & 2300 & 2400 & 2500 & 2600 & 2700 & 2800 & 2900 & 3000 & 3100 & 3200 \\
\hline 0.70 & & & & & & * & & & & \\
\hline 0.71 & & & & & & $*$ & & & & \\
\hline 0.72 & & & & & & $*$ & & & & \\
\hline 0.73 & & & & & & $*$ & & & & \\
\hline 0.74 & & & & & & $*$ & & & & \\
\hline 0.75 & & & & & & * & * & & & \\
\hline 0.76 & & & & & & & * & & & \\
\hline 0.77 & & & & & & & * & & & \\
\hline 0.78 & & & & & & & $*$ & & & \\
\hline 0.79 & & & & & & & * & & & \\
\hline 0.80 & & & & & & & * & & & \\
\hline 0.81 & & & & & & & $*$ & & & \\
\hline 0.82 & & & & & & & $*$ & $*$ & & \\
\hline 0.83 & & & & & & & & * & & \\
\hline 0.84 & & & & & & & & * & & \\
\hline 0.85 & & & & & & & & * & & \\
\hline 0.86 & & & & & & & & * & & \\
\hline 0.87 & & & & & & & & & & \\
\hline 0.88 & & & & & & & & & * & \\
\hline 0.89 & & & & & & & & & $*$ & \\
\hline 0.90 & & & & & & & & & $*$ & \\
\hline
\end{tabular}




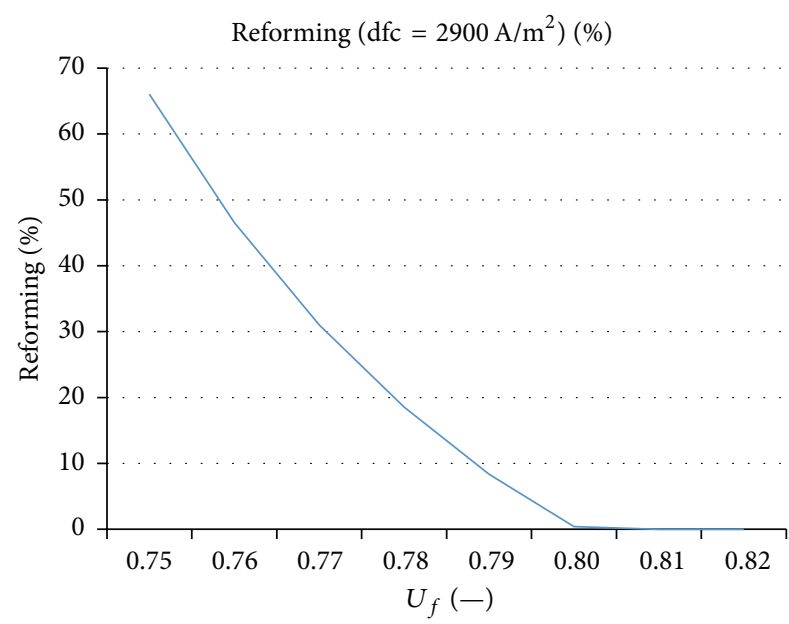

Figure 6: Percentage of prereforming at varying $U_{f}$.

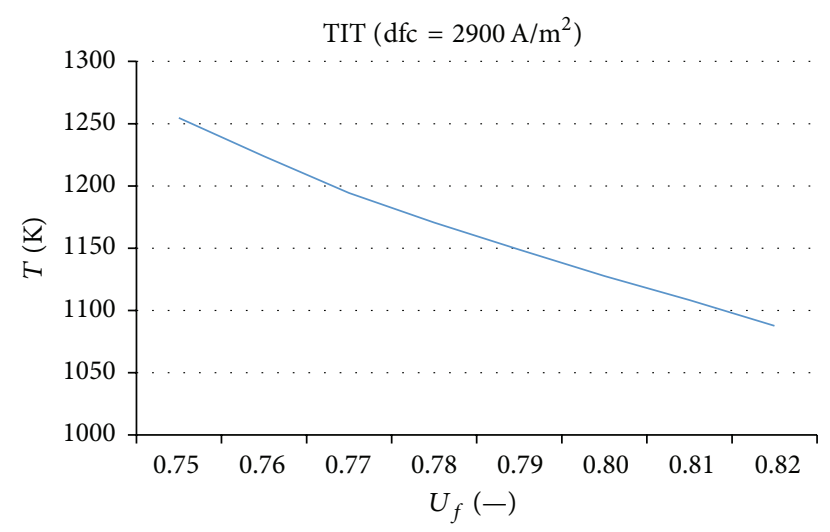

FIGURE 7: TIT at varying $U_{f}$.

as well (second effect), so that temperatures should increase. The first effect prevails on the second one. Therefore, the overall effect is a lowering of all operating temperatures of the hybrid system. Consequently, the temperature being lower, to keep the anode inlet temperature at the desired value, an inferior amount of methane flow has to be reformed before entering the cell. Thus, the percentage of reforming decreases, as Figure 6 shows. Figure 7, owing to the already described effects, shows how the temperature at the turbine inlet monotonically decreases and the turbogas power depending on the TIT (TIT decrease means a decreasing in $\Delta h$, thus a reduction in useful power, according to (31) and (32)); this means also a decreasing in terms of MTG power, as one can observe in Figure 8. Instead, a nonmonotonous trend is that concerning the power of the cell. In fact, this is affected, for low values of $U_{f}$, by a prereforming effect, which changes the composition in the anode input (reactions (5) and (6)). Therefore, according to (16), the composition change means that the percentage of reforming decreases, while Nernstlosses increase, causing an overall power decrease in the stack. Therefore, when it is no longer necessary to reform, the Nernst-loss decreases with decreasing temperature, so that the power of the cell starts growing (Figure 9). Finally,

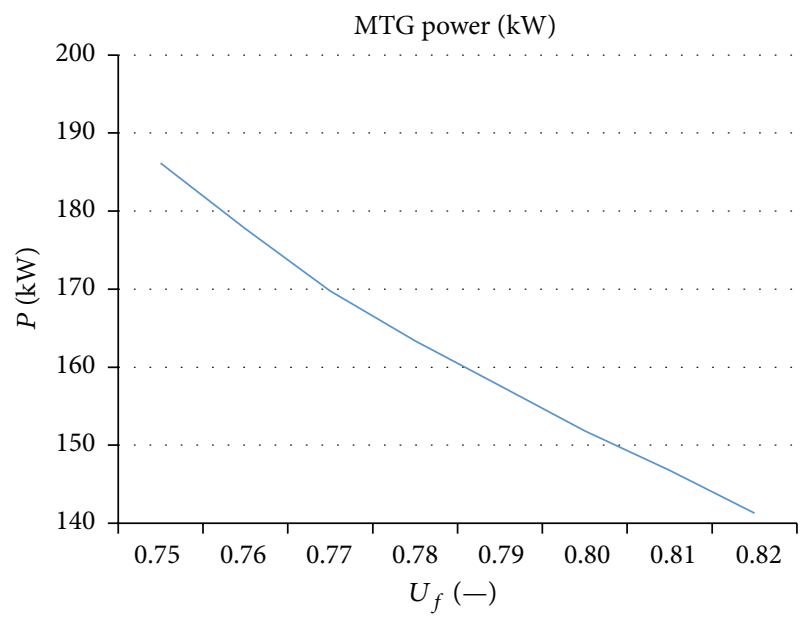

FIgURE 8: Turbogas power at varying $U_{f}$.

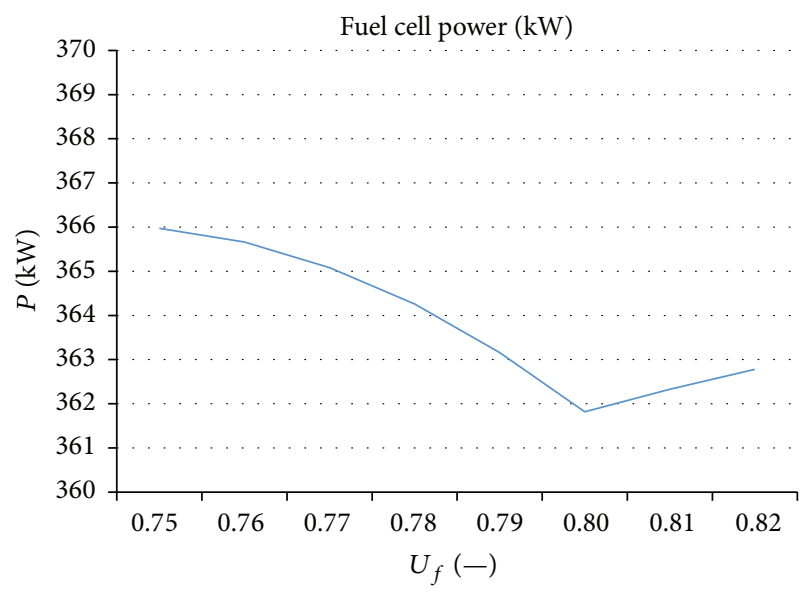

FIGURE 9: Fuel cell power at varying $U_{f}$.

it is interesting to note that, with increasing $U_{f}$, while overall performance parameters decrease, there is an increase in the index IRE (Figure 10), whereas the thermal limit remains nearly constant.

\section{Discussion}

6.1. First Validation of the Calculation Model. A first testing of the model calculation was carried out, both of a qualitative and of a quantitative nature. The "trend" of some fundamental parameters with respect to developments known from the literature was evaluated, and the results obtained here were compared with those calculated in [3].

6.2. Qualitative Validation. First, for purpose of qualitative model validation, the data obtained were compared, for the same $U_{f}$, for different values of dfc. As we expected, Table 7 shows that an increase of the current density causes an increase of the operating temperature of the hybrid system and, consequently, an increase in the percentage of methane on which it performs the prereforming. Table 8 shows that, 


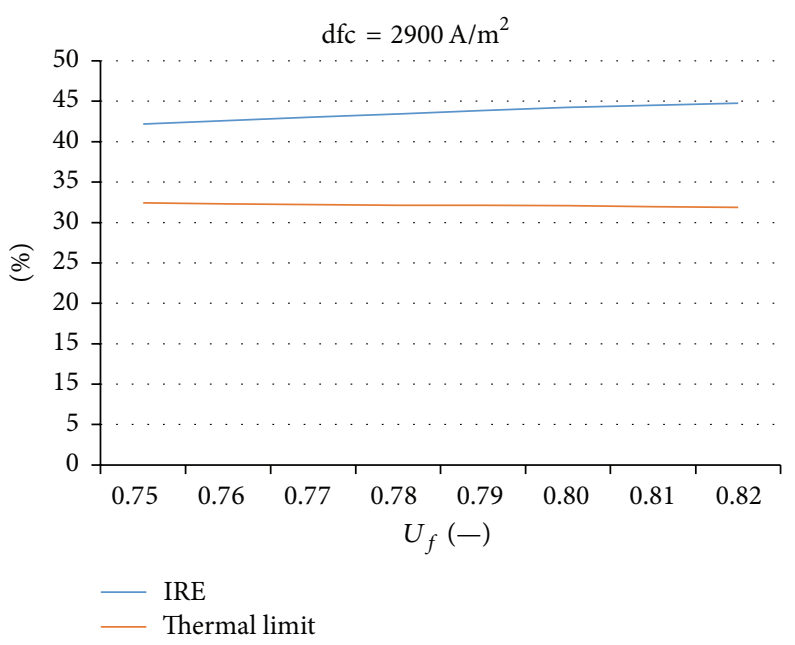

Figure 10: IRE (blue) and LT (red) at varying $U_{f}$.

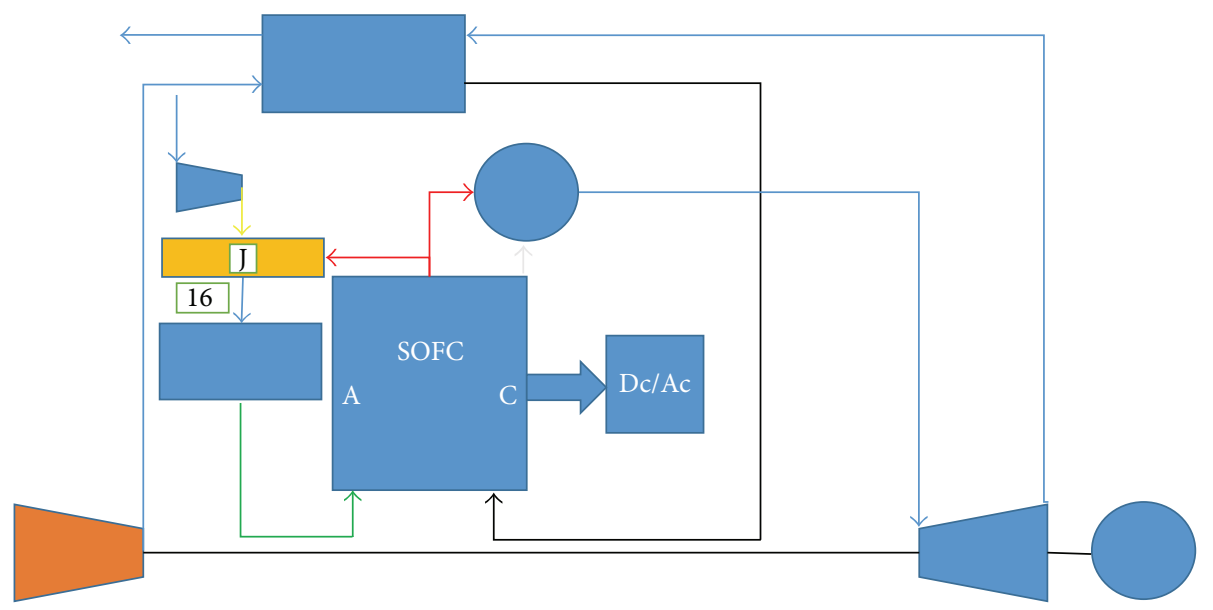

FIGURE 11: Hybrid system studied in [3].

with the increase of $\mathrm{dfc}$, both the cell (despite an increase in voltage losses) and the gas turbine power rise, the second being directly dependent on the turbine inlet temperature.

6.3. Quantitative Validation. To end the first validation process, the model was applied to the system of Figure 15, studied in [3], and results were compared. In [3] the methane is compressed to 30 bars instead of the operating pressure of the MTG and then joined in a mixer and blend, with associated losses, from the anode recirculation. The mixer is the only difference compared to the complete system. The thermodynamic modeling of the mixer and of the ejector inside it would be very complex. In homologous conditions, the results turn out better for the complete system (consistent with the physical principles). Thus, one objective was to evaluate, in a first approximation, how the ejector affects the losses, using equivalent useful area as a parameter. This is defined as the percentage of usable area of Figure 3 hybrid system, compared with that of Figure 11 (without ejector), such that, in homologous operating conditions, both systems produce the same power. The results are as shown in Table 9.
It is seen that when the area is reduced up to $85 \%$ of the given "plate," the relative difference between the reference data and the data provided by the model remains around $1 \%$, thus lending credibility to the mathematical model described in this paper.

\section{Conclusions}

The objective set at the beginning was to define the optimal conditions of operation of the hybrid system by developing a $\mathrm{C}++$ code and to evaluate the suitability of this approach with the physical and chemical process present inside the SOFC-MTG plant. In the first instance we see that the optimal configuration of the hybrid system is that of the complete system. This ensures both a satisfactory temperature management and good values of gas turbine power. The flow rate of methane is excellent, given the guaranteed, high design flexibility, which is defined as $\dot{m}_{m}$, that is, $0.015 \mathrm{~kg} / \mathrm{s}$. For the said value of the flow rate of methane, current density that ensures the best compromise between performance and degrees of freedom to the designer (varying $U_{f}$ eligible 
TABLE 7: Operating parameters in equal value $U_{f}$ for different $\mathrm{dfc}$.

\begin{tabular}{lccccccccc}
\hline $\mathrm{dfc}\left[\mathrm{A} / \mathrm{m}^{2}\right]$ & $U_{f}$ & \%recirculation & $T_{\text {mix }}[\mathrm{K}]$ & \%reforming & $T_{\text {an }}[\mathrm{K}]$ & $T_{\text {cat }}[\mathrm{K}]$ & $T_{\mathrm{fc}}[\mathrm{K}]$ & $\mathrm{TIT}$ & $T_{\text {out }}[\mathrm{K}]$ \\
\hline 2800 & 0.75 & 83.43 & 823.3 & 0 & 823.3 & 619.71 & 851.73 & 1088.27 & 821.46 \\
2900 & 0.75 & 86.17 & 1007.15 & 66.07 & 873 & 683.74 & 1050 & 1254.57 & 947.45 \\
2900 & 0.82 & 77.24 & 831.16 & 0 & 831.16 & 620.1 & 874.53 & 1087.75 & 821.47 \\
3000 & 0.82 & 81.69 & 995.97 & 45.59 & 873 & 676.38 & 1052 & 1235.74 & 933.23 \\
\hline
\end{tabular}

TABLE 8: Performance parameters for different dfc.

\begin{tabular}{|c|c|c|c|c|c|c|}
\hline $\mathrm{dfc}\left[\mathrm{A} / \mathrm{m}^{2}\right]$ & $U_{f}$ & Voltage [V] & Voltage losses [V] & $\dot{P}_{\mathrm{uc}}[\mathrm{kW}]$ & $\dot{P}_{\mathrm{tg}}[\mathrm{kW}]$ & $\dot{P}_{\text {tot }}[\mathrm{kW}]$ \\
\hline 2900 & 0.82 & 0.6788 & 0.5058 & 362.78 & 141.28 & 504.06 \\
\hline 3000 & 0.82 & 0.6619 & 0.5227 & 365.96 & 180.78 & 546.74 \\
\hline
\end{tabular}

TABLE 9: Comparison of the data obtained with the model and experimental data studied by evaluating an equivalent useful area equal to $85 \%$ of the effective area $\left(\mathrm{dfc}=3200 \mathrm{~A} / \mathrm{m}^{2}\right)$.

\begin{tabular}{lccc}
\hline & Model data & Reference data & $\begin{array}{c}\text { Relative difference } \\
{[\%]}\end{array}$ \\
\hline $\begin{array}{l}\text { Hybrid system } \\
\text { power [kW] }\end{array}$ & 431.47 & 428 & 0.80 \\
$\begin{array}{l}\text { Fuel cell power } \\
{[\mathrm{kW}]}\end{array}$ & 320.52 & 319 & 0.47 \\
$\begin{array}{l}\text { Gas turbine } \\
\text { power }[\mathrm{kW}]\end{array}$ & 110.95 & 109 & 1.76 \\
\hline $\begin{array}{l}\text { Hybrid system } \\
\text { efficiency }[\mathrm{kW}]\end{array}$ & 0.62 & 0.61 & \\
$\begin{array}{l}\text { Fuel cell } \\
\text { efficiency }[\mathrm{kW}]\end{array}$ & 0.46 & 0.45 & \\
$\begin{array}{l}\text { Gas turbine } \\
\text { efficiency }[\mathrm{kW}]\end{array}$ & 0.16 & 0.16 & \\
\hline
\end{tabular}

between 0.75 and 0.82 ) is that of $2900 \mathrm{~A} / \mathrm{m}^{2}$. The last step is the choice of operating $U_{f}$, which may vary depending on the objective it set out: choosing a low $U_{f}$ if there is directed towards energy optimization, $U_{f}$ high if the goal is to maximize the cogeneration yield, and a medium $U_{f}$ if seeking a compromise between the two requirements. Since systems of this type are still under study, of the 3 options described above, at the current state of the art, it seems to make sense to focus on energy optimization, and when consolidated on the market, there will be consideration later with the economic scenario of the moment. This factor is closely related to the evaluation of the investment from the perspective of cogeneration. The developed $\mathrm{C}++$ code matches with both the state of the art and reference data taken from the literature, suggesting the suitability of this approach to evaluate and describe SOFC-MTG and other kinds of plants.

\section{Nomenclature}

$A_{f}$ : Useful area of the fuel cell $\left[\mathrm{m}^{2}\right]$

$c_{p}$ : Specific heat at constant pressure $[\mathrm{J} /(\mathrm{mol} \cdot \mathrm{K})]$ $c_{p_{m}}:$ Average specific heat of the mixture in the course of expansion $[\mathrm{J} /(\mathrm{kg} \cdot \mathrm{K})]$

$c_{v}: \quad$ Specific heat at constant volume $[\mathrm{J} /(\mathrm{mol} \cdot \mathrm{K})]$

dfc: Current density with which it operates within the fuel cell $\left[\mathrm{A} / \mathrm{m}^{2}\right]$

F: $\quad$ Faraday constant, that is, $96485[\mathrm{C} / \mathrm{mol}]$

$f_{\mathrm{CO}}$ : Molar fraction of carbon monoxide, dimensionless

$f_{\mathrm{H}_{2}}$ : Molar fraction of hydrogen, dimensionless

$h_{\text {air }}:$ Molar enthalpy of the air $[\mathrm{J} / \mathrm{mol}]$

$h_{\mathrm{CH}_{4}}:$ Molar enthalpy of methane [J/mol]

$h_{\mathrm{CO}} \quad$ Molar enthalpy of carbon monoxide [J/mol]

$h_{\mathrm{CO}_{2}}:$ Molar enthalpy of carbon dioxide $[\mathrm{J} / \mathrm{mol}]$

$h_{\mathrm{H}_{2}}:$ Molar enthalpy of hydrogen [J/mol]

$h_{\mathrm{H}_{2} \mathrm{O}}$ : Molar enthalpy of the water vapor $[\mathrm{J} / \mathrm{mol}]$

$h_{\mathrm{O}_{2}}$ : Molar enthalpy of oxygen [J/mol]

$h_{\mathrm{N}_{2}}$ : Molar enthalpy of nitrogen $[\mathrm{J} / \mathrm{mol}]$

$I: \quad$ Operation current [A]

IRE: "Energy saving index," dimensionless

$i 0_{a}$ : Current density exchange anode side $\left[\mathrm{A} / \mathrm{m}^{2}\right]$

$i 0_{c}$ : $\quad$ Current density exchange cathode side $\left[\mathrm{A} / \mathrm{m}^{2}\right]$

il: $\quad$ Limit current density $\left[\mathrm{A} / \mathrm{m}^{2}\right]$

$K_{\text {ref }}$ : Equilibrium constant of the reaction of steam reforming, dimensionless

$K_{\text {shif }}$ : Equilibrium constant of the reaction of Water Gas Shift Reaction, dimensionless

$\dot{m}: \quad$ Air mass flow rate $[\mathrm{kg} / \mathrm{s}]$

$\dot{m}_{\mathrm{CH}_{4}}$ : Methane mass flow rate $[\mathrm{kg} / \mathrm{s}]$

$\dot{m}_{t}: \quad$ Mass flow rate in the expander $[\mathrm{kg} / \mathrm{s}]$

$n_{\mathrm{CH}_{4}}:$ Methane molar flow [mol/s]

$n_{\mathrm{CO}}$ : Carbon monoxide molar flow rate $[\mathrm{mol} / \mathrm{s}]$

$n_{\mathrm{H}_{2}}$ : Hydrogen molar flow rate $[\mathrm{mol} / \mathrm{s}]$

$n_{\mathrm{H}_{2} \mathrm{O}}$ : Steam molar flow rate $[\mathrm{mol} / \mathrm{s}]$

$\dot{P}: \quad$ Electric power obtained through the electrochemical reaction of water formation [W]

$\dot{P}_{\mathrm{ac}}$ : Power absorbed by the compressor gas turbine system [W] 


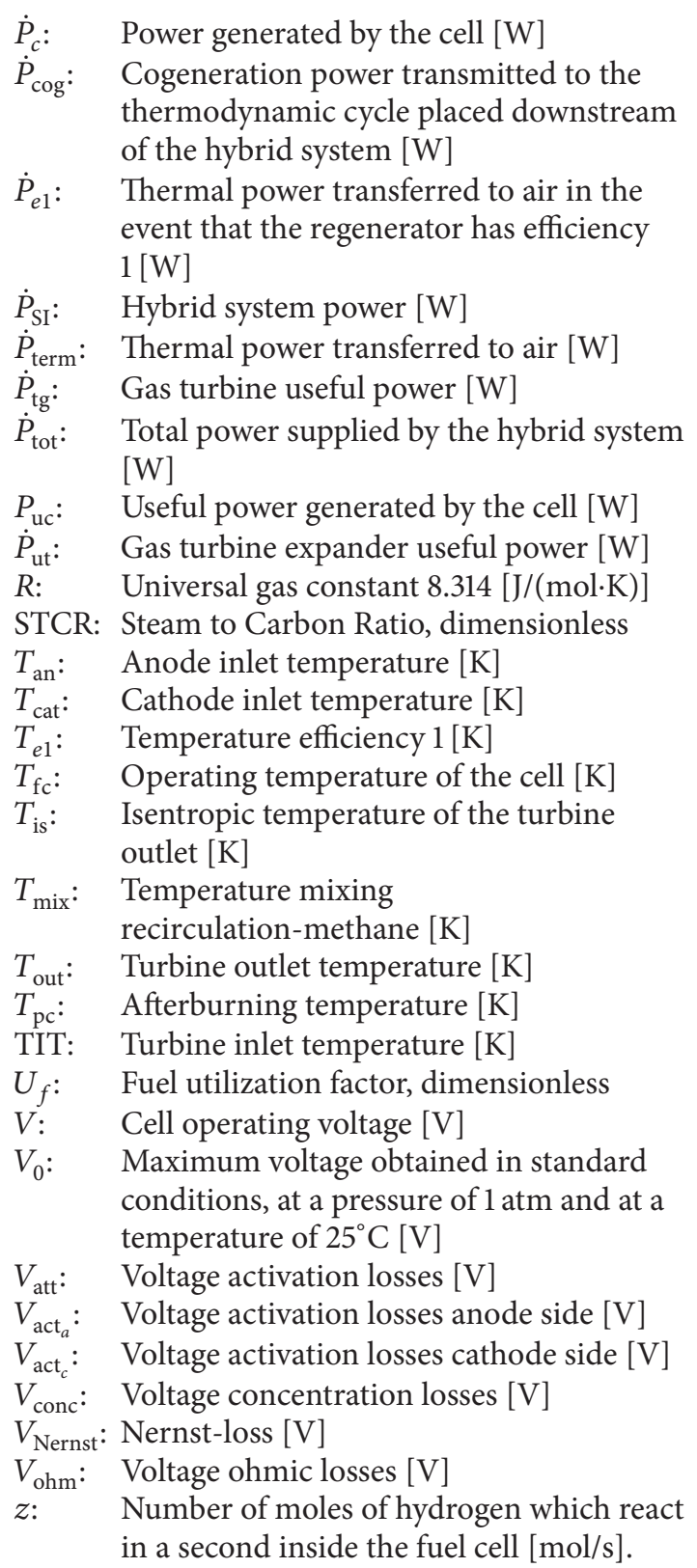

\section{Greek Alphabet}

$$
\begin{array}{ll}
\beta: & \begin{array}{l}
\text { Compression ratio, dimensionless } \\
\Delta G^{0}:
\end{array} \\
& \begin{array}{l}
\text { Variation in Gibbs free energy in } \\
\text { formation water reaction }-228600[\mathrm{~J} / \mathrm{mol}]
\end{array} \\
\Delta h_{\mathrm{CO}_{2}}: \begin{array}{l}
\text { Standard enthalpy of formation of carbon } \\
\text { monoxide oxidation reaction [J/mol] }
\end{array} \\
\Delta h_{\mathrm{H}_{2} \mathrm{O}}: \begin{array}{l}
\text { Enthalpy of formation of electrochemical } \\
\text { water formation reaction [J/mol] }
\end{array} \\
\Delta h_{\mathrm{ref}}: \begin{array}{l}
\text { Enthalpy of formation in reforming } \\
\text { reaction [J/mol] }
\end{array} \\
\Delta h_{\text {shif }}: \begin{array}{l}
\text { Enthalpy of formation in shifting reaction } \\
{[\mathrm{J} / \mathrm{mol}]}
\end{array} \\
\eta_{c}: \quad \text { Cell efficiency, dimensionless } \\
\eta_{\text {comb }}: \quad \text { Combustion efficiency, dimensionless }
\end{array}
$$

$\eta_{\text {inv }}:$ Inverter conversion efficiency, dimensionless

$\eta_{\mathrm{is}, c}:$ Isentropic efficiency of the compressor, dimensionless

$\eta_{\mathrm{is}, t}:$ Isentropic efficiency of the turbine, dimensionless

$\eta_{\mathrm{SI}}: \quad$ Hybrid system efficiency, dimensionless

$\eta_{\text {term }}:$ Thermal efficiency, dimensionless

$\eta_{\mathrm{tg}}: \quad$ Gas turbine efficiency, dimensionless

$\sigma_{a}: \quad$ Anode resistivity $\left[\Omega^{-1} \cdot \mathrm{mm}\right]$

$\sigma_{c}: \quad$ Cathode resistivity $\left[\Omega^{\cdot 1} \cdot \mathrm{mm}\right]$

$\sigma_{e}: \quad$ Electrolyte resistivity $\left[\Omega^{-1} \cdot \mathrm{mm}\right]$

$\sigma_{i}: \quad$ Interconnection resistivity $\left[\Omega^{-1} \cdot \mathrm{mm}\right]$.

\section{Subscripts}

ifc: Fuel cell inlet

ip: Prereformer inlet

ipc: Afterburner inlet

it: Turbine inlet

ofc: Fuel cell outlet

opc: Afterburner outlet

ric: Recirculation.

\section{Conflict of Interests}

The authors declare that there is no conflict of interests regarding the publication of this paper.

\section{References}

[1] A. Demirbas, "Fuel cells as clean energy converters," Energy Sources Part A: Recovery, Utilization, and Environmental Effects, vol. 29, no. 2, pp. 185-191, 2007.

[2] Z. Ziaka and S. Vasileiadis, "Pretreated landfill gas conversion process via a catalytic membrane reactor for renewable combined fuel cell-power generation," Journal of Renewable Energy, vol. 2013, Article ID 209364, 8 pages, 2013.

[3] A. Pontecorvo, R. Tuccillo, and F. Bozza, Studio di una microturbina a gas per sistemi cogenerativi ed ibridi [Ph.D. thesis], Università degli Studi di Napoli Federico II, Napoli, Italy, 2010.

[4] F. Bozza, M. C. Cameretti, and R. Tuccillo, "Adapting the micro-gas turbine operation to variable thermal and electrical requirements," ASME Paper 2003-GT-38652, 2003.

[5] F. Bozza and R. Tuccillo, "Transient operation analysis of a cogenerating micro-gas turbine," ASME Paper ESDA 200458079, 2004.

[6] M. C. Cameretti and R. Tuccillo, "Comparing different solutions for the micro-gas turbine combustor," ASME Paper 2004-GT53286, 2004.

[7] R. Tuccillo, "Performance and transient behaviour of MTG based energy systems," Tech. Rep. RTO-MP-AVT-131 VKI/LS, Micro Gas Turbines, 2005.

[8] S. H. Chan, H. K. Ho, and Y. Tian, "Modelling of simple hybrid solid oxide fuel cell and gas turbine power plant," Journal of Power Sources, vol. 109, no. 1, pp. 111-120, 2002.

[9] S. K. Nayak and D. N. Gaonkar, "Modeling and performance analysis of microturbine generation system in grid connected/islanding operation," Journal of Renewable Energy, vol. 2, no. 4, pp. 750-757, 2012. 
[10] C. Stiller, B. Thorud, and O. Bolland, "Safe dynamic operation of a simple SOFC/GT hybrid system," ASME Paper 2005-GT68481, ASME, 2005.

[11] S. H. Chan, H. K. Ho, and Y. Tian, "Multi-level modeling of SOFC-gas turbine hybrid system," International Journal of Hydrogen Energy, vol. 28, no. 8, pp. 889-900, 2003.

[12] L. Barelli, G. Bidini, F. Gallorini, and P. A. Ottaviano, "Design optimization of a SOFC-based CHP system through dynamic analysis," International Journal of Hydrogen Energy, vol. 38, no. 1, pp. 354-369, 2013.

[13] H.-W. D. Chiang, C.-N. Hsu, W.-B. Huang, C.-H. Lee, W.-P. Huang, and W.-T. Hong, "Design and performance study of a solid oxide fuel cell and gas turbine hybrid system applied in combined cooling, heating, and power system," Journal of Energy Engineering, vol. 138, no. 4, pp. 205-214, 2012.

[14] L. Barelli, G. Bidini, and P. A. Ottaviano, "Part load operation of SOFC/GT hybrid systems: stationary analysis," International Journal of Hydrogen Energy, vol. 37, no. 21, pp. 16140-16150, 2012.

[15] P. Chinda and P. Brault, "The hybrid solid oxide fuel cell (SOFC) and gas turbine (GT) systems steady state modeling," International Journal of Hydrogen Energy, vol. 37, no. 11, pp. 9237-9248, 2012.

[16] X. Zhang, J. Guo, and J. Chen, "Influence of multiple irreversible losses on the performance of a molten carbonate fuel cellgas turbine hybrid system," International Journal of Hydrogen Energy, vol. 37, no. 10, pp. 8664-8671, 2012.

[17] L. Leto, C. Dispenza, A. Moreno, and A. Calabrò, "Simulation model of a molten carbonate fuel cell-microturbine hybrid system," Applied Thermal Engineering, vol. 31, no. 6-7, pp. $1263-$ 1271, 2011.

[18] O. Corigliano, G. Florio, and P. Fragiacomo, "A numerical simulation model of high temperature fuel cells fed by biogas," Energy Sources Part A: Recovery, Utilization and Environmental Effects, vol. 34, no. 2, pp. 101-110, 2011.

[19] G. De Lorenzo and P. Fragiacomo, "Technical analysis of an ecofriendly hybrid plant with a microgas turbine and an MCFC system," Fuel Cells, vol. 10, no. 1, pp. 194-208, 2010.

[20] G. De Lorenzo and P. Fragiacomo, "A methodology for improving the performance of molten carbonate fuel cell/gas turbine hybrid systems," International Journal of Energy Research, vol. 36, no. 1, pp. 96-110, 2012.

[21] S. Wongchanpai, H. I. Wai, M. Saito, and H. Yoshida, "Performance evaluation of a direct biogas solid oxide fuel cell-micro gas turbine (SOFC-MTG) hybrid combined heat and power (CHP) system," Journal of Power Sources, vol. 223, pp. 9-17, 2013.

[22] R. Toonssen, S. Sollai, P. V. Aravind, N. Woudstra, and A. H. M. Verkooijen, "Alternative system designs of biomass gasification SOFC/GT hybrid systems," International Journal of Hydrogen Energy, vol. 36, no. 16, pp. 10414-10425, 2011.

[23] Y. Zhao, J. Sadhukhan, A. Lanzini, N. Brandon, and N. Shah, "Optimal integration strategies for a syngas fuelled SOFC and gas turbine hybrid," Journal of Power Sources, vol. 196, no. 22, pp. 9516-9527, 2011.

[24] P. V. Aravind, C. Schilt, B. Türker, and T. Woudstra, "Thermodynamic model of a very high efficiency power plant based on a biomass gasifier, SOFCs, and a gas turbine," International Journal of Renewable Energy Development, vol. 1, no. 2, pp. 5155, 2012.

[25] C. Bang-Møller and M. Rokni, “Thermodynamic performance study of biomass gasification, solid oxide fuel cell and micro gas turbine hybrid systems," Energy Conversion and Management, vol. 51, no. 11, pp. 2330-2339, 2010.
[26] C. Bao, N. Cai, and E. Croiset, "A multi-level simulation platform of natural gas internal reforming solid oxide fuel cellgas turbine hybrid generation system-part II. Balancing units model library and system simulation," Journal of Power Sources, vol. 196, no. 20, pp. 8424-8434, 2011.

[27] S. Douvartzides and P. Tsiakaras, "Thermodynamic and economic analysis of a steam reformer-solid oxide fuel cell system fed by natural gas and ethanol," Energy Sources, vol. 24, no. 4, pp. 365-373, 2002.

[28] D. F. Cheddie and R. Murray, "Thermo-economic modeling of a solid oxide fuel cell/gas turbine power plant with semidirect coupling and anode recycling," International Journal of Hydrogen Energy, vol. 35, no. 20, pp. 11208-11215, 2010.

[29] Y. Zhao, N. Shah, and N. Brandon, "Comparison between two optimization strategies for solid oxide fuel cell-gas turbine hybrid cycles," International Journal of Hydrogen Energy, vol. 36, no. 16, pp. 10235-10246, 2011.

[30] U. G. Bossel and B. C. H. Swiss, Final Report on SOFC Data facts and Figures, Federal Office of Energy, 1992.

[31] O. Levenspiel, Ingegneria delle reazioni chimiche, Casa Editrice Ambrosiana, Milano, Italy, 1972. 


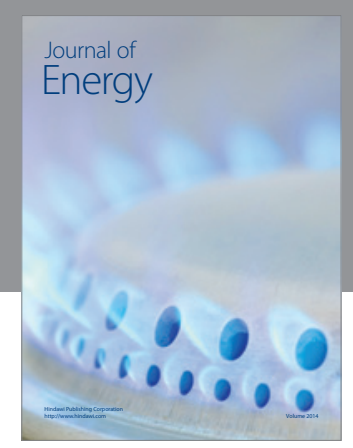

Journal of

Industrial Engineering
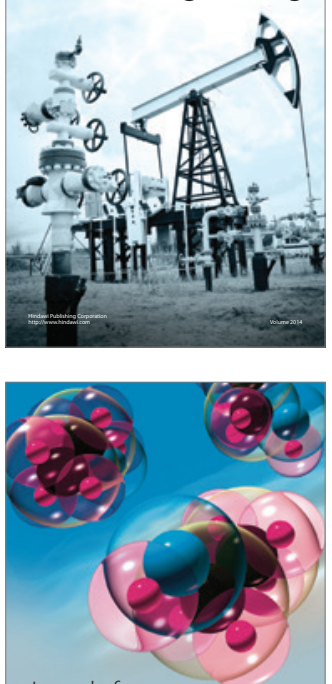

Fuels
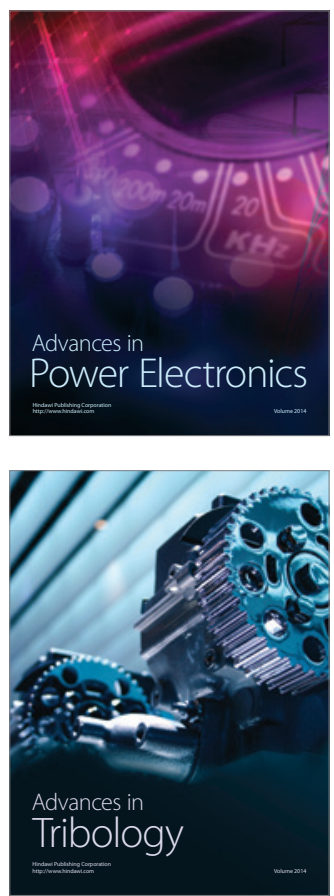

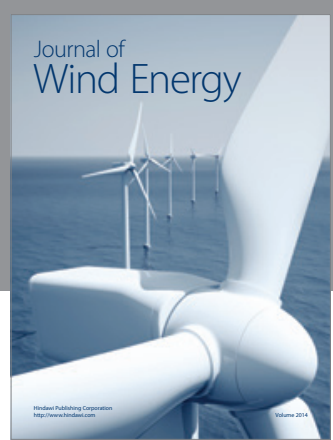

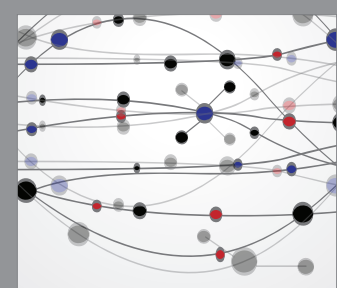

The Scientific World Journal

Submit your manuscripts at http://www.hindawi.com

Journal of

Structures
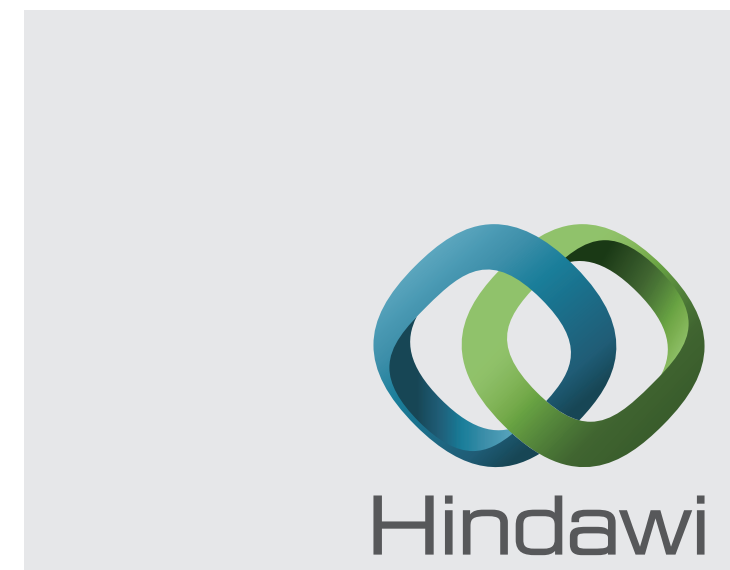

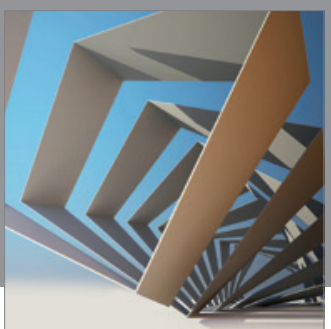

Rotating

Machinery
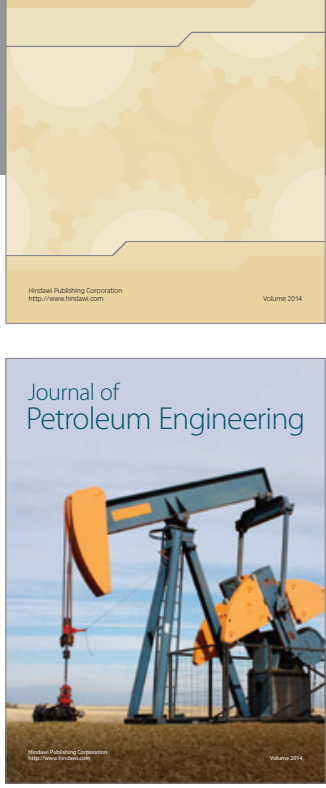

Journal of

Solar Energy
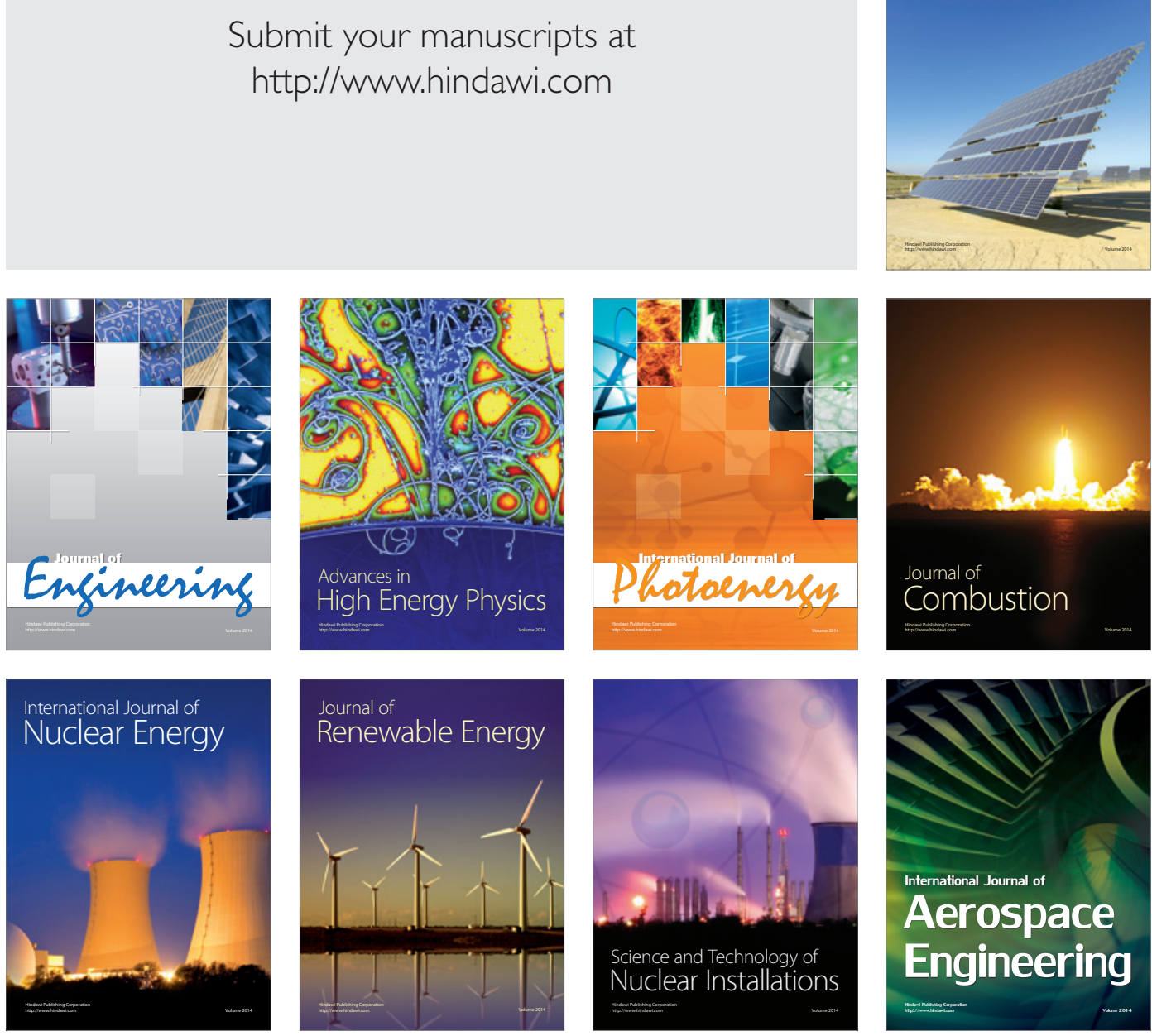